\title{
MENINGITIS AND ENCEPHALITIS IN POLAND IN 2019*
}

\section{ZAPALENIA OPON MÓZGOWO-RDZENIOWYCH I ZAPALENIA MÓZGU W POLSCE W 2019 ROKU*}

\author{
National Institute of Public Health NIH - National Research Institute \\ Department of Epidemiology of Infectious Diseases and Surveillance \\ Narodowy Instytut Zdrowia Publicznego PZH - Państwowy Instytut Badawczy \\ Zakład Epidemiologii Chorób Zakaźnych i Nadzoru
}

\begin{abstract}
INTRODUCTION. The most common form of infectious diseases of the nervous system is meningitis and encephalitis. This study discusses in detail bacterial meningitis and/or encephalitis in which the etiological factors are: Neisseria meningitidis, Streptococcus pneumoniae, Haemophilus influenzae and viral - in Poland, most often caused by tick-borne encephalitis virus. In addition to routine epidemiological surveillance of diseases caused by these etiological factors, mandatory and recommended vaccinations are carried out in Poland aimed at reducing the number of cases caused by $N$. meningitidis, S. pneumoniae, H. influenzae and TBEV.

AIM OF THE STUDY. The aim of the study is to assess the epidemiological situation of meningitis and encephalitis in Poland in 2019.

MATERIAL AND METHODS. The epidemiological situation of meningitis and encephalitis in Poland was assessed on data sent to NIPH NIH - NRI by voivodeship sanitary-epidemiological stations and published in the annual bulletin "Infectious diseases and poisoning in Poland in 2019" and "Vaccinations in Poland in 2019". RESULTS. In 2019, a total of 2,239 cases of meningitis and encephalitis were registered in Poland. This is a decrease by approximately $19,9 \%$ compared to 2018 . In the case of bacterial infections, including neuroborreliosis, the number of cases decreased by 27\%, from 1265 to 921 cases. In the group of viral infections, a decrease by $14 \%$ (from 1,533 to 1,318 cases) was recorded. In $31 \%$ of all the cases of bacterial etiology, the etiological factor was one of three: Neisseria meningitidis, Streptococcus pneumoniae and Haemophilus influenzae. Infections of viral etiology accounted for $58.9 \%$ of all registered cases. Compared to 2018 , the number of $S$. pneumoniae cases decreased by $14.6 \%$, and in the case of $N$. meningitidis by $6.9 \%$. In the case of $H$. influenzae, there was an increase in the number of cases, compared to the previous year. In addition, there was a slight increase in the number of cases of tick-borne encephalitis - from 197 cases in 2018 to 265 cases in 2019 (an increase of 34.5\%).

SUMMARY AND CONCLUSION. The analysis showed a generally declining disease trend, both in bacterial and viral meningitis and encephalitis. Only in cases caused by H. influenzae and tick-borne encephalitis virus, an increase was observed compared to the previous year. Meningitis and encephalitis continues to be a challenge for the healthcare system, with particular emphasis on the correct differentiation of the etiology at an early stage of infection detection.
\end{abstract}

Key words: meningitis, encephalitis, epidemiology, Poland, 2019

\section{STRESZCZENIE}

WSTĘP. Najczęstszą postacią chorób zakaźnych układu nerwowego jest zapalenie opon mózgowo-rdzeniowych i/lub mózgu. W niniejszym opracowaniu omówiono szczegółowo zapalenia opon mózgowo-rdzeniowych i/lub mózgu o podłożu bakteryjnym, w których czynnikami etiologicznymi były: Neisseria meningitidis, Streptococcus pneumoniae, Haemophilus influenzae oraz o podłożu wirusowym - w Polsce najczęściej wywoływa-

* The work was carried out as part of task No. BE-1/2020 / Praca została wykonana w ramach zadania nr BE-1/2020

C National Institute of Public Health NIH - National Research Institute / Narodowy Instytut Zdrowia Publicznego PZH - Państwowy Instytut Badawczy 
ne przez wirus kleszczowego zapalenia mózgu. Poza rutynowo prowadzonym nadzorem epidemiologicznym nad chorobami wywołanymi przez wymienione czynniki etiologiczne, prowadzone są w Polsce obowiązkowe i zalecane szczepienia mające na celu ograniczenie liczby zachorowań wywołanych przez N. meningitidis, $S$. pneumoniae, H. influenzae i KZM.

CEL PRACY. Celem pracy była ocena epidemiologiczna występowania zachorowań na zapalenie opon mózgowo-rdzeniowych i zapalenia mózgu w Polsce w 2019 r.

MATERIAL I METODY. Do przeprowadzenia analizy epidemiologicznej występowania zapalenia opon mózgowo-rdzeniowych i/lub zapaleń mózgu wykorzystano dane nadsyłane do NIZP PZH - PIB przez Wojewódzkie Stacje Sanitarno-Epidemiologiczne, a następnie publikowane w biuletynach rocznych: „Choroby zakaźne i zatrucia w Polsce” oraz „Szczepienia ochronne w Polsce”.

WYNIKI. W roku 2019 zarejestrowano w Polsce ogółem 2239 zachorowań na zapalenie opon mózgowo-rdzeniowych i/lub mózgu. Jest to spadek liczby zachorowań o 19,9\% w porównaniu do roku 2018. W przypadku infekcji o etiologii bakteryjnej, z uwzględnieniem neuroboreliozy, liczba zachorowań zmniejszyła się o $27 \%$ (z 1265 do 921). W grupie infekcji o podłożu wirusowym odnotowano spadek o 14\% (z 1533 do 1318 zachorowań). Spośród wszystkich zachorowań o etiologii bakteryjnej, w $31 \%$ przypadków czynnikiem etiologicznym był jeden z trzech drobnoustrojów: Neisseria meningitidis, Streptococcus pneumoniae, Haemophilus influenzae. Spośród wszystkich zarejestrowanych zachorowań, 58,9\% stanowiły infekcje o etiologii wirusowej. W porównaniu do roku 2018 liczba zachorowań o etiologii S. pneumoniae spadła o 14,6\%, a w przypadku N. meningitidis o $6,9 \%$. W przypadku $H$. influenzae, odnotowano wzrost liczby zachorowań względem roku ubiegłego. Ponadto, obserwowano niewielki wzrost liczby zachorowań na kleszczowe zapalenie mózgu - z 197 przypadków w 2018 roku do 265 w 2019 roku (wzrost o 34,5\%).

PODSUMOWANIE I WNIOSKI. Analiza wykazała ogólnie spadkową tendencję zachorowań, zarówno w przypadku zapaleń opon mózgowo-rdzeniowych i/lub mózgu o podłożu bakteryjnym, jak i wirusowym. Może to świadczyć m.in. o skuteczności prowadzonych programów szczepień. Jedynie w przypadku zachorowań wywołanych przez $H$. influenzae oraz wirus kleszczowego zapalenia mózgu, zaobserwowano wzrost w porównaniu do roku poprzedniego. Zapalenie opon mózgowo-rdzeniowych i/lub mózgu nadal stanowi wyzwanie dla systemu opieki zdrowotnej, ze szczególnym naciskiem na prawidłowe różnicowanie etiologii już na wczesnym etapie wykrycia zakażenia.

Słowa kluczowe: zapalenie opon mózgowo-rdzeniowych, zapalenie mózgu, epidemiologia, Polska, rok 2019

\section{INTRODUCTION}

Due to the etiology, meningitis and encephalitis can be divided into bacterial and viral (1). Streptococcus pneumoniae, Haemophilus influenzae and Neisseria meningitidis, transmitted by airborne droplets, are the main causes of bacterial meningitis and encephalitis (2). In Poland, tick-borne encephalitis virus (TBEV) is the dominant etiological factor in viral meningitis and encephalitis. The infection is most often caused by a tick bite. However, there are cases of infection through the consumption of unpasteurized milk from an animal in the viremic stage, in particular raw goat's milk (3).

In order to prevent meningitis and encephalitis, vaccines are used in Poland against diseases caused by: N. meningitidis, S. pneumoniae, $H$. influenzae and tick-borne encephalitis virus.

According to the Protective Vaccination Program, in 2019, meningococcal vaccinations belong to the group of recommended vaccinations and can be used from 2 months of age. For $N$. meningitidis, the following vaccines are available: monovalent conjugate vaccine against serogroup $\mathrm{C}$; monovalent

\section{WSTĘP}

Ze względu na etiologię, zapalenia opon mózgowo -rdzeniowych oraz zapalenia mózgu można podzielić na te o podłożu bakteryjnym oraz wirusowym (1). Streptococcus pneumoniae, Haemophilus influenzae oraz Neisseria meningitidis, przenoszone drogą kropelkową, są głównymi przyczynami bakteryjnego zapalenia opon mózgowo-rdzeniowych i/lub mózgu (2). W Polsce, dominującym czynnikiem etiologicznym zapalenia opon mózgowo-rdzeniowych i/lub mózgu o podłożu wirusowym jest wirus kleszczowego zapalenia mózgu (KZM). Do zakażenia dochodzi najczęściej w następstwie ukłucia przez kleszcza. Jednak zdarzają się przypadki zakażenia poprzez spożycie niepasteryzowanego mleka pochodzącego od zwierzęcia będącego w fazie wiremii, w szczególności surowego mleka koziego (3).

W celu zapobiegania zapaleniom opon mózgowo -rdzeniowych i/lub mózgu, w Polsce stosowane są szczepionki przeciw chorobom wywołanym zarówno przez $N$. meningitidis, S. pneumoniae, $H$. influenzae jak i wirus kleszczowego zapalenia mózgu. 
recombinant combined, adsorbed, vaccine against serogroup $\mathrm{B}$; conjugate, quadrivalent vaccine against serogroups A, C, W-135, Y and unconjugated vaccine (polysaccharide) against serogroups A, C - administered to children over 2 years of age. and adults (4).

Vaccination against $S$. pneumoniae, starting from 2017, are included in the group of compulsory vaccinations for children from 2 months of age up to 5 years of age from high-risk groups with special health indications. In addition, this vaccination is still recommended for adults over 65 years of age, as well as for children up to 5 years of age from risk groups other than those mentioned in the case of compulsory vaccination (4).

Vaccination against $H$. influenzae type $\mathrm{B}$ is compulsory for children from 2 months of age. Additionally, it is a vaccination recommended for children up to 6 years of age who have not yet been vaccinated under compulsory vaccinations and for older children from risk groups, e.g. after removal of the spleen (4).

Vaccination against tick-borne encephalitis is recommended by the Ministry of Health to all persons residing in areas characterized by high prevalence of this disease (4).

Despite the vaccination strategy in place, antibiotic therapy and universal access to medical care, the mortality and incidence due to bacterial meningitis remain high in developing and developed countries. On the other hand, viral meningitis and encephalitis usually has a good prognosis and is cured within one or two weeks without any treatment (5). For most viral infections in this regard, there is no specific treatment other than symptomatic treatment.. Many can be prevented by vaccination and protection of the dermis against vectors carrying viral infections (6). Early differentiation of bacterial and viral meningitis and encephalitis, along with appropriate antibiotic therapy, significantly improve patients' prognosis and reduce mortality (1).

\section{AIM OF THE STUDY}

The aim of the study is to assess the epidemiological situation of meningitis and encephalitis in Poland in 2019.

\section{MATERIAL AND METHODS}

To carry out comparative analysis and epidemiological assessment of the occurrence of meningitis and/or encephalitis, data sent to NIPH NIH - NRI by voivodeship sanitary-epidemiological stations and published in annual bulletins and
Zgodnie z Programem Szczepień Ochronnych (PSO), w 2019 r. szczepienia przeciw meningokokom należą do grupy szczepień zalecanych i mogą być stosowane już od 2 m.ż. W przypadku $N$. meningitidis dostępne są następujące szczepionki: szczepionka skoniugowana monowalentna przeciw serogrupie $C$; szczepionka rekombinowana monowalentna złożona, adsorbowana przeciw serogrupie B; szczepionka skoniugowana czterowalentna przeciw serogrupom A, C, W-135, Y oraz szczepionka nieskoniugowana (polisacharydowa), przeciw serogrupom $\mathrm{A}, \mathrm{C}$ - podawana dzieciom powyżej 2 r. ż. oraz dorosłym (4).

Szczepienia przeciw $S$. pneumoniae, począwszy od 2017 roku są włączone do grupy szczepień obowiązkowych dla dzieci od 2 m.ż. do 5 r.ż. z grup podwyższonego ryzyka, ze szczególnymi wskazaniami zdrowotnymi. Ponadto, szczepienie to nadal jest zalecane osobom dorosłym osobom powyżej 65 r.ż., a także dzieciom do 5 r.ż. z grup ryzyka innych niż te wymienione w przypadku szczepień obowiązkowych (4).

Szczepienie przeciw $H$. influenzae typu B jest obowiązkowe dla dzieci od 2 m.ż. Dodatkowo, jest to szczepienie zalecane dzieciom do 6 roku życia nieszczepionym dotychczas $w$ ramach szczepień obowiązkowych oraz dzieciom starszym, z grup ryzyka, np. po usunięciu śledziony (4).

Szczepienia przeciw kleszczowemu zapaleniu mózgu zalecane są przez Ministerstwo Zdrowia wszystkim osobom przebywającym na obszarach charakteryzujących się nasilonym występowaniem tej choroby (4).

Pomimo obowiązującej strategii szczepień, antybiotykoterapii i powszechnego dostępu do opieki medycznej, zachorowalność i umieralność z powodu bakteryjnego zapalenia opon mózgowych są nadal wysokie, zarówno w krajach rozwijających się, jak i rozwiniętych. $Z$ drugiej strony, wirusowe zapalenie opon mózgowo-rdzeniowych i/lub mózgu ma zwykle dobre rokowanie i może być wyleczone w ciągu jednego lub dwóch tygodni (5). W przypadku większości zakażeń wirusowych nie ma specyficznego leczenia, poza leczeniem objawowym. Wielu zachorowaniom można zapobiegać poprzez szczepienia i ochronę skóry właściwej przed wektorami przenoszącymi zakażenia wirusowe (6). Wczesne zróżnicowanie bakteryjnego i wirusowego zapalenia opon mózgowo-rdzeniowych i/lub mózgu, wraz z odpowiednią antybiotykoterapią, znacznie poprawiają rokowanie pacjentów i zmniejszają umieralność (1).

\section{CEL PRACY}

Celem pracy jest ocena epidemiologiczna występowania zachorowań na zapalenie opon mózgowo-rdzeniowych oraz zapalenia mózgu w Polsce w 2019 roku. 
individual epidemiological interviews from the electronic Epidemiological Interview Recording System were used $(4,7)$.

Classification of infections was made on the basis of definitions of infectious disease cases developed for the needs of epidemiological surveillance (version in force in 2019, Department of Epidemiology of Infectious Disease and Surveillance, NIPH-NIH). Case definitions were used for: $N$. meningitidis, $S$. pneumoniae, $H$. influenzae and tick-borne encephalitis. The analysis of the vaccination status against selected diseases took into account the recommendations of the "Protective Vaccination Program for 2019" (Annex to the Communication of the Chief Sanitary Inspector of October 25, 2018).

\section{RESULTS}

\section{BACTERIAL MENINGITIS AND ENCEPHALITIS}

In 2019, 921 cases of bacterial meningitis and encephalitis, including neuroborreliosis were registered in Poland (incidence 2.41 per 100,000). This is a decrease by $37.35 \%$ compared to the previous year, when the number of cases amounted to 1265 (incidence 3.30 per 100,000) (Table I). In the group of 921 cases, in 286 people (31\%), the etiological factor was one of three: N. meningitidis, S. pneumoniae, and $H$. influenzae. In this group, meningococcal and pneumococcal infections in total accounted for $96.5 \%$. There were also 294 cases of neuroborreliosis, accounting for $31.92 \%$ of all bacterial infections. (Table II).

Overall, the most cases of meningitis and encephalitis were recorded in śląskie voivodeship 80 cases (incidence 1.77 per 100,000), and the lowest in podlaskie voivodeship - 13 cases (incidence 1.10 per 100,000). The highest incidence was recorded in pomorskie voivodeship (2.65 per 100,000), and the lowest in podlaskie voivodeship, 1.10 per 100,000 (Table III).

In the case of etiological factors such as $N$. meningitidis, S. pneumoniae and other specified/ unspecified factors, a higher incidence was reported among men than women. The largest difference was in the incidence of other specific/unspecified etiology infections: 0.98 per 100,000 for men and 0.59 for women and S. pneumoniae: 0.61 per 100,000 for men and 0.34 per 100,000 for women. Only in the case of $H$. influenzae infections was the incidence slightly higher in the group of women -0.03 vs. 0.02 per 100,000 among men. In 2019, we observed a decrease in the incidence among men with regard to $N$. meningitidis, $S$. pneumoniae, compared to the

\section{MATERIAŁ I METODY}

Do przeprowadzenia oceny epidemiologicznej występowania zapalenia opon mózgowo-rdzeniowych i/ lub zapalenia mózgu wykorzystano dane przesyłane do NIZP PZH - PIB przez Wojewódzkie Stacje Sanitarno -Epidemiologiczne, które publikowane są w biuletynach rocznych oraz jednostkowe wywiady epidemiologiczne z elektronicznego Systemu Rejestracji Wywiadów Epidemiologicznych $(4,7)$.

Klasyfikacja zakażeń została dokonana w oparciu o definicje przypadków chorób zakaźnych opracowanych na potrzeby nadzoru epidemiologicznego (wersja obowiązująca w roku 2019, Zakład Epidemiologii Chorób Zakaźnych i Nadzoru, NIZP-PZH). Definicje przypadków zastosowano dla: $N$. meningitidis, S. pneumoniae, H. influenzae oraz kleszczowego zapaleniu mózgu.

Analiza stanu zaszczepienia przeciw wybranym chorobom uwzględniała zalecenia „Programu Szczepień Ochronnych na rok 2019" (Załącznik do Komunikatu Głównego Inspektora Sanitarnego z dnia 25 października 2018 r.).

\section{WYNIKI}

\section{ZAPALENIE OPON MÓZGOWO- RDZENIOWYCH I ZAPALENIE MÓZGU O ETIOLOGII BAKTERYJNEJ}

W roku 2019, w Polsce zarejestrowano 921 zachorowań na zapalenie opon mózgowo-rdzeniowych i/lub mózgu o etiologii bakteryjnej, z uwzględnieniem przypadków neuroboreliozy (zapadalność 2,41 na 100 tys.). Jest to spadek o $37,35 \%$ w porównaniu do roku ubiegłego, kiedy liczba zachorowań wyniosła 1265 (zapadalność 3,3 na 100 tys.) (Tab. I). W grupie 921 przypadków, u 286 osób (31\%) czynnikiem etiologicznym był jeden z trzech drobnoustrojów: $N$. meningitidis, S. pneumoniae, $H$. influenzae. Odnotowano także 294 przypadki neuroboreliozy, co stanowi 31,92\% wszystkich zakażeń bakteryjnych.

Ogółem, najwięcej zachorowań na zapalenie opon mózgowo-rdzeniowych i/lub mózgu, zarejestrowano w województwie śląskim - 80 przypadków (zapadalność 1,77 na 100 tys.), najmniej zaś w województwie podlaskim - 13 przypadków (zapadalność 1,10 na 100 tys.). Najwyższą zapadalność odnotowano w województwie pomorskim (2,65 na 100 tys.), a najniższą w województwie podlaskim 1,10 na 100 tys. (Tab. III).

W przypadku czynników etiologicznych takich jak: N. meningitidis, S. pneumoniae oraz innych określonych/nieokreślonych odnotowano wyższą zapadalność wśród mężczyzn niż kobiet. Największa różnica dotyczyła zapadalności w przypadku zakażeń o innej określonej/nieokreślonej etiologii: 0,98 na 100 tys. dla 
Table I. Meningitis and/or encephalitis. Number of cases and incidence per 100,000 population by etiological agent in 2018 and 2019

Tabela I. Zapalenia opon i/lub mózgu. Zachorowania i zapadalność na 100 tys. mieszkańców wg czynnika etiologicznego w 2018 oraz 2019 roku

\begin{tabular}{|c|c|c|c|c|c|c|c|c|}
\hline \multirow[b]{2}{*}{$\begin{array}{l}\text { Etiologia } \\
\text { (Etiology) }\end{array}$} & \multirow[b]{2}{*}{$\begin{array}{c}\text { Jednostka } \\
\text { chorobowa } \\
\text { (Disease) }\end{array}$} & \multirow[b]{2}{*}{$\begin{array}{l}\text { Czynnik etiologiczny } \\
\text { (Etiological factor) }\end{array}$} & \multicolumn{3}{|c|}{2018} & \multicolumn{3}{|c|}{2019} \\
\hline & & & 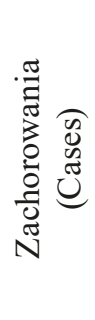 & 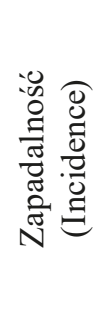 & 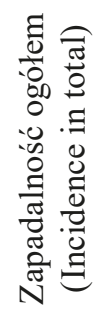 & 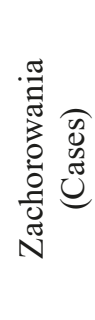 & 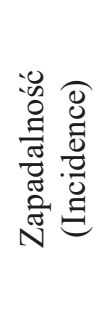 & 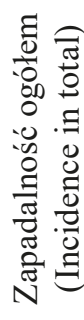 \\
\hline \multirow{7}{*}{ 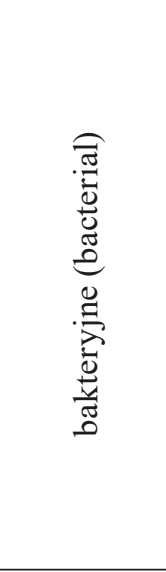 } & \multirow{7}{*}{ 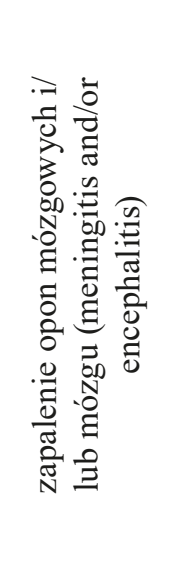 } & Neisseria meningitidis & 102 & 0,27 & \multirow{7}{*}{2,28} & 95 & 0,25 & \multirow{7}{*}{2,41} \\
\hline & & Haemophilus influenzae & 6 & 0,03 & & 10 & 0,03 & \\
\hline & & Streptococcus pneumoniae & 212 & 0,55 & & 181 & 0,47 & \\
\hline & & $\begin{array}{l}\text { inne określone (G00.2-G00.8; } \\
\text { G04.2) (other specified) }\end{array}$ & 120 & 0,31 & & 122 & 0,32 & \\
\hline & & $\begin{array}{l}\text { inne nieokreślone (G00.9; } \\
\text { G04.2) (other unspecified) }\end{array}$ & 216 & 0,56 & & 177 & 0,46 & \\
\hline & & $\begin{array}{l}\text { w innych chorobach objętych } \\
\text { obowiązkiem zgłaszania } \\
\text { (reported in other diseases) }\end{array}$ & 217 & 0,56 & & 42 & 0,11 & \\
\hline & & $\begin{array}{l}\text { Neuroborelioza } \\
\text { (neuroborreliosis) }\end{array}$ & $392 *$ & $1,02^{*}$ & & 294 & 0,77 & \\
\hline \multirow{9}{*}{ 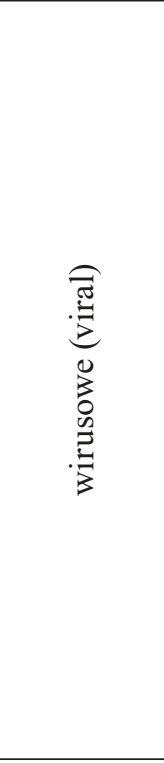 } & \multirow{5}{*}{ 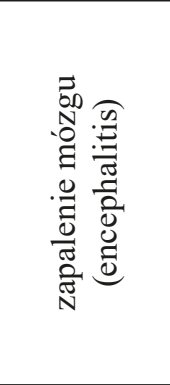 } & kleszczowe (tick-borne) & 197 & 0,51 & \multirow{9}{*}{3,99} & 265 & 0,69 & \multirow{9}{*}{3,43} \\
\hline & & opryszczkowe (herpesviral) & 17 & 0,04 & & 21 & 0,05 & \\
\hline & & inne określone (other specified) & 4 & 0,01 & & 8 & 0,02 & \\
\hline & & nieokreślone (unspecified) & 79 & 0,21 & & 63 & 0,16 & \\
\hline & & $\begin{array}{c}\text { w innych chorobach objętych } \\
\text { obowiązkiem zgłaszania, NGI } \\
\text { (reported in other diseases, not } \\
\text { elsewhere classified) }\end{array}$ & 10 & 0,03 & & 11 & 0,03 & \\
\hline & \multirow{4}{*}{ 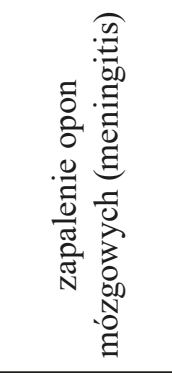 } & enterowirusowe (enteroviral) & 110 & 0,29 & & 134 & 0,35 & \\
\hline & & opryszczkowe (herpesviral) & 3 & 0,008 & & 2 & 0,005 & \\
\hline & & \begin{tabular}{|c|} 
inne określone i nieokreślone \\
(other specified and unspecified)
\end{tabular} & 1108 & 2,88 & & 807 & 2,10 & \\
\hline & & $\begin{array}{c}\text { w innych chorobach objętych } \\
\text { obowiązkiem zgłaszania, NGI } \\
\text { (reported in other diseases, not } \\
\text { elsewhere classified) }\end{array}$ & 5 & 0,01 & & 7 & 0,02 & \\
\hline \multicolumn{3}{|c|}{ RAZEM (TOTAL) } & 2798 & & & 2239 & & \\
\hline
\end{tabular}

\footnotetext{
* brak danych dla neuroboreliozy w związku z wprowadzeniem odrębnej rejestracji od 2019, wyliczone na potrzeby porównania
}

* no data for neuroborreliosis due to new registration method since 2019, calculated for comparison

previous year. On the other hand, among women there was an increase in the incidence of $N$. meningitidis and $H$. influenzae compared to 2018. In the group of women, the incidence of $S$. pneumoniae decreased compared to the previous year. When analyzing the incidence by place of residence, in 2019 - in rural areas we do not record any significant changes compared to the previous year. However, in urban areas we observe an increase in the incidence only in the case of $H$. influenzae infections. (Table IV). mężczyzn i 0,59 dla kobiet oraz $S$. pneumoniae: 0,61 na 100 tys. dla mężczyzn oraz 0,34 na 100 tys. dla kobiet. Jedynie w przypadku zakażeń $H$. influenzae zapadalność była nieznacznie wyższa $\mathrm{w}$ grupie kobiet $-0,03$ vs. 0,02 na 100 tys. u mężczyzn. W roku 2019, obserwowano spadek zapadalności na infekcje opon mózgowo-rdzeniowych i/lub mózgu u mężczyzn wywołane przez $N$. meningitidis i $S$. pneumoniae w porównaniu do roku ubiegłego. Natomiast wśród kobiet odnotowano wzrost zapadalności w przypadku $N$. meningitidis. 
Table II. Bacterial meningitis and/or encephalitis. Number of cases and incidence per 100,000 population by etiological agent in 2018 and 2019

Tabela II Bakteryjne zapalenia opon i/lub mózgu. Zachorowania i zapadalność na 100 tys. mieszkańców wg czynnika etiologicznego w 2018 oraz 2019 roku

\begin{tabular}{|c|c|c|c|c|c|}
\hline \multirow{2}{*}{$\begin{array}{l}\text { Jednostka } \\
\text { chorobowa } \\
\text { (Disease) }\end{array}$} & \multirow{2}{*}{$\begin{array}{l}\text { Czynnik etiologiczny } \\
\text { (Etiological factor) }\end{array}$} & \multicolumn{2}{|c|}{2018} & \multicolumn{2}{|c|}{2019} \\
\hline & & $\begin{array}{l}\text { Zachorowania } \\
\text { (Cases) }\end{array}$ & $\begin{array}{c}\text { Zapadalność } \\
\text { (Incidence) }\end{array}$ & $\begin{array}{l}\text { Zachorowania } \\
\text { (Cases) }\end{array}$ & $\begin{array}{l}\text { Zapadalność } \\
\text { (Incidence) }\end{array}$ \\
\hline \multirow{7}{*}{$\begin{array}{l}\text { zapalenie opon } \\
\text { mózgowych } \\
\text { i/lub mózgu } \\
\text { (meningitis and/ } \\
\text { or encephalitis) }\end{array}$} & Neisseria meningitidis & 102 & 0,27 & 95 & 0,25 \\
\hline & Haemophilus influenzae & 6 & 0,03 & 10 & 0,03 \\
\hline & Streptococcus pneumoniae & 212 & 0,55 & 181 & 0,47 \\
\hline & $\begin{array}{l}\text { inne określone (G00.2-G00.8; } \\
\text { G04.2) (other specified) }\end{array}$ & 120 & 0,31 & 122 & 0,32 \\
\hline & $\begin{array}{l}\text { inne nieokreślone (G00.9; } \\
\text { G04.2) (other unspecified) }\end{array}$ & 216 & 0,56 & 177 & 0,46 \\
\hline & $\begin{array}{l}\text { w innych chorobach objętych } \\
\text { obowiązkiem zgłaszania } \\
\text { (reported in other diseases) }\end{array}$ & 217 & 0,56 & 42 & 0,11 \\
\hline & Neuroborelioza & $392 *$ & $1,02 *$ & 294 & 0,77 \\
\hline \multicolumn{2}{|c|}{ RAZEM (TOTAL) } & 1265 & 3,30 & 921 & 2,41 \\
\hline
\end{tabular}

* brak danych dla neuroboreliozy w związku z wprowadzeniem odrębnej rejestracji od 2019, wyliczone na potrzeby porównania

* no data for neuroborreliosis due to new registration method since 2019, calculated for comparison

Table III. Bacterial meningitis and/or encephalitis. Number of cases and incidence per 100,000 population by voivodeships in 2019*

Tabela III. Bakteryjne zapalenie opon i/lub mózgu. Liczba zachorowań oraz zapadalność na 100 tys. mieszkańców wg województw w 2019 roku*

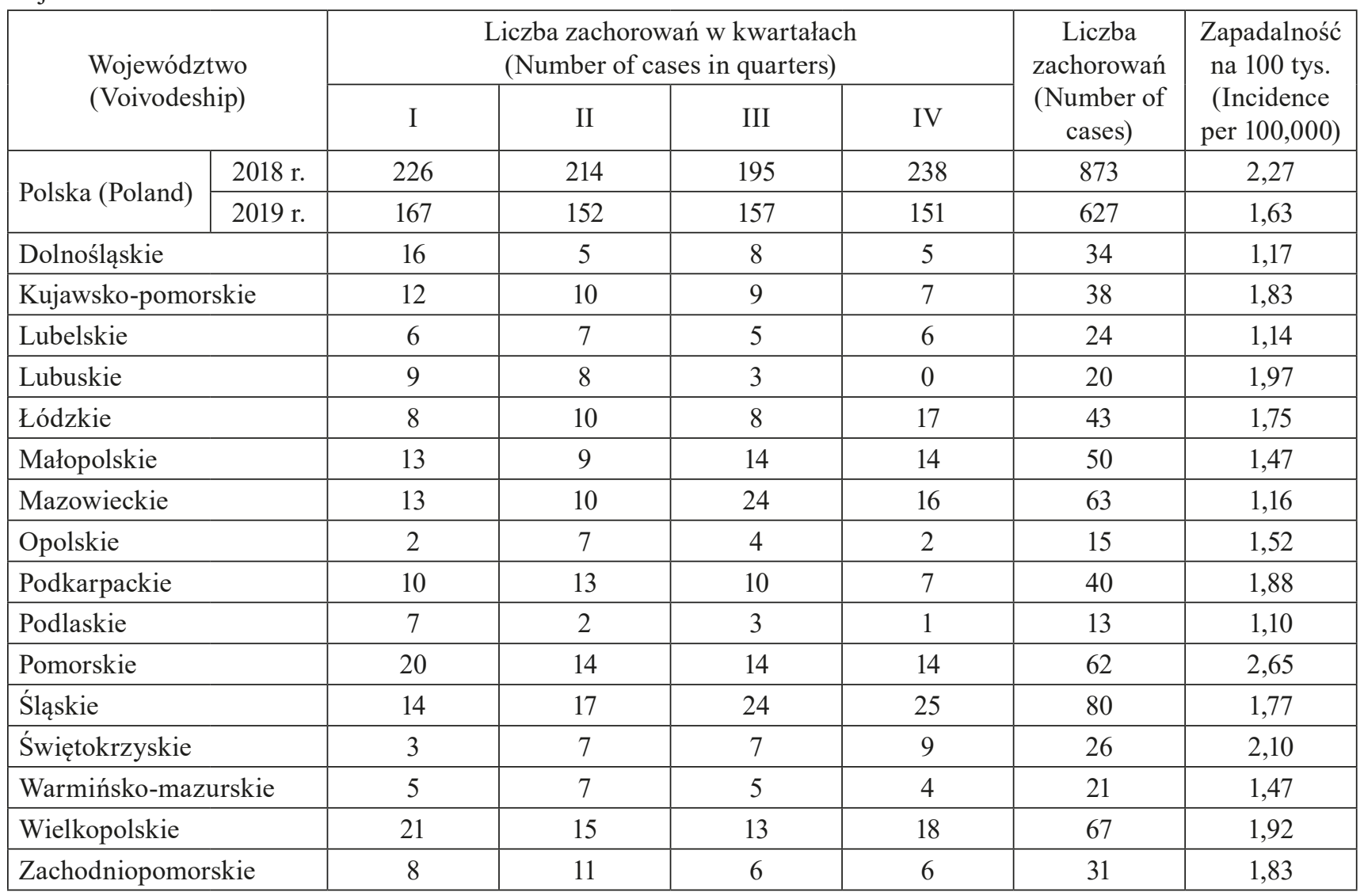

* without neuroborreliosis 
In 2019, people aged 45-64 (30.26\% of all infections) and children up to 4 years of age were the most exposed to bacterial meningitis and encephalitis $(20.34 \%$ of all reported infections). The highest number of $S$. pneumoniae infections occurred in people aged 45-64, but the highest incidence was recorded in children under 4 years of age. In the group of people over 65 years of age, $S$. pneumoniae infections were more prevalent $(23.2 \%$ of all pneumococcal infections). The highest number of infections caused by $N$. meningitidis was observed among children up to 4 years of age $-44.21 \%$ of all infections (Table V).

Neisseria meningitidis. In 2019, there were 95 cases of meningococcal meningitis and encephalitis (incidence 0.25 per 100,000 ). This means a decrease in infections of this etiology by $6.86 \%$ compared to the previous year (Table I). The highest incidence was recorded among children under 4 years of age (2.19 per 100,000), in this age group accounted for $44.21 \%$ of all meningococcal infections. (Table V).

In 2019, $N$. meningitidis infections were more common in men, regardless of where they lived. Compared to the previous year, there was also a decrease in the incidence among men from 0.37 to 0.28 per 100,000 . The opposite was true for women, where the incidence increased from 0.17 to 0.22 per 100,000 . In the case of meningococcal infections, the incidence in rural and urban areas is comparable, with a slightly higher incidence in rural areas, respectively: 0.26 and 0.24 per 100,000 . In 2018, an inverse relationship was found: a slightly higher incidence in the urban areas: 0.27 per 100,000 compared to rural areas: 0.26 per 100,000 (Table IV).

In 2019, the most cases caused by $N$. meningitidis were recorded in wielkopolskie voivodeship - 16 cases (incidence 0.46 per 100,000), and the lowest in podlaskie voivodeship -1 case (incidence 0.08 per 100,000). Compared to 2018, most voivodeships either recorded a decrease in the number of meningococcal infections or remained at the same level. In the case of six voivodships, we observed a slight increase in the number of infections compared to the previous year: lubelskie - by $25 \%$, łódzkie - by $20 \%$, mazowieckie - by $13 \%$, opolskie - by $50 \%$, świętokrzyskie - by 40 $\%$, wielkopolskie - by $6 \%$. In addition, the highest number of meningococcal infections occurred in the first quarter of 2019 - 33 cases, then we observe a decrease until the third quarter - to 16 cases, and then a further increase in the fourth quarter - to 23 cases. A similar tendency was recorded in 2018 (Table VI).

In 2019, the number of people vaccinated against diseases caused by $N$. meningitidis was 98,952 , i.e. by $0.74 \%$ more than in 2018 (98,223 people). This group i H. influenzae w porównaniu do roku 2018. Wśród kobiet odnotowano spadek zapadalności w przypadku S. pneumoniae względem roku ubiegłego. Analizując zapadalność wg miejsca zamieszkania, w 2019 roku na obszarach wiejskich nie różniła się istotnie względem roku poprzedniego. Natomiast na obszarach miejskich, wystąpił wzrost zapadalności jedynie w przypadku zakażeń H. influenzae (Tab. IV).

W roku 2019, na bakteryjne zapalenie opon mózgowo-rdzeniowych i/lub mózgu najczęściej chorowały osoby w przedziale wieku 45-64 lata (30,26\% wszystkich zakażeń) oraz dzieci do 4 r.ż. (20,34\% wszystkich zgłoszonych zakażeń). Najwyższa liczba zakażeń o etiologii S. pneumoniae wystąiła u osób w przedziale wieku 45-64 lata, jednak najwyższą zapadalność odnotowano u dzieci poniżej 4 r.ż. W grupie osób powyżej 65 r.ż. zanotowano przewagę zakażeń $S$. pneumoniae (23,2\% wszystkich zakażeń pneumokokowych). Największą liczbę zakażeń wywołanych $N$. meningitidis zaobserwowano u dzieci do 4 r.ż. - 44,21\% wszystkich zakażeń (Tab. V).

Neisseria meningitidis. W roku 2019, odnotowano 95 przypadków meningokokowego zapalenia opon mózgowo-rdzeniowych i/lub mózgu (zapadalność 0,25 na 100 tys.). Oznacza to spadek liczby zakażeń o tej etiologii o $6,86 \%$ względem roku ubiegłego (Tab. I). Najwyższą zapadalność zarejestrowano wśród dzieci poniżej 4 r.ż. (2,19 na 100 tys.), zachorowania w tej grupie wieku stanowiły 44,21\% wszystkich zakażeń meningokokowych (Tab. V).

W 2019 r. zakażenia $N$. meningitidis występowały częściej u mężczyzn niż u kobiet, niezależnie od miejsca zamieszkania. Względem roku ubiegłego obserwowano spadek zapadalności mężczyzn z 0,37 do 0,28 na 100 tys. Natomiast $u$ kobiet, odnotowano wzrost zapadalności z 0,17 do 0,22 na 100 tys. W przypadku zakażeń meningokokowych, zapadalność na wsi i w mieście jest porównywalna, z nieznacznie wyższą zapadalnością na wsi, odpowiednio: 0,26 i 0,24 na 100 tys. W roku 2018 odnotowano zależność odwrotną: nieznacznie wyższą zapadalność w mieście: 0,27 na 100 tys. w porównaniu do wsi: 0,26 na 100 tys. (Tab. IV).

W roku 2019, najwięcej zachorowań wywołanych $N$. meningitidis zanotowano $\mathrm{w}$ województwie wielkopolskim - 16 przypadków (zapadalność 0,46 na 100 tys.), najmniej zaś w województwie podlaskim - 1 przypadek (zapadalność 0,08 na 100 tys.). W porównaniu do roku 2018 w większości województw zaobserwowano albo spadek liczby zakażeń meningokokowych, albo utrzymywały się one na tym samym poziomie. $\mathrm{W}$ przypadku sześciu województw obserwowano nieznaczny wzrost liczby zakażeń w stosunku do roku ubiegłego: województwo lubelskie - o $25 \%$, województwo łódzkie - o $20 \%$, województwo mazowieckie - o $13 \%$, województwo opolskie - o 50\%, województwo święto- 


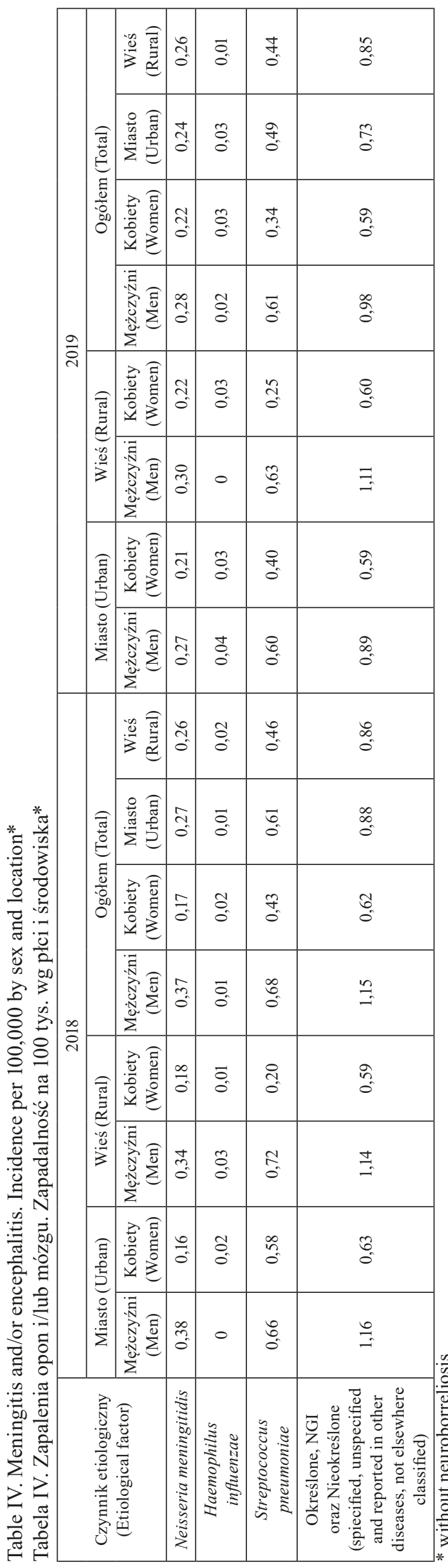

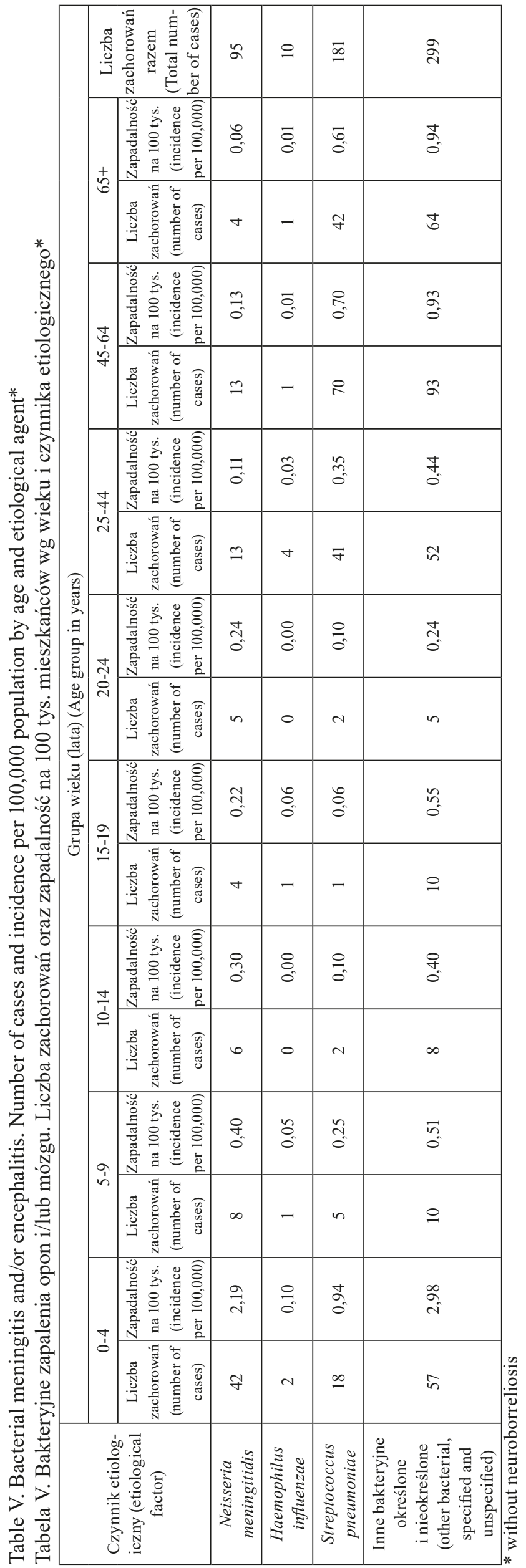


included $92.39 \%$ of children and adolescents under 19 years of age (4).

Haemophilus influenzae type B. The number of cases of $H$. influenza type $B$ meningitis and encephalitis increased from 6 in 2018 to 10 in 2019. However, the incidence remains at the same level, due to the generally low number of cases -0.03 per 100,000 both in 2018 and 2019 (Table II). In 2019, cases were registered in 6 voivodeships: dolnośląskie -2 cases, mazowieckie - 2 cases, podkarpackie -1 case, pomorskie -1 case, śląskie -2 cases, zachodniopomorskie -2 cases (1). The incidence among women was higher than in men ( 0.03 vs. 0.02 per 100,000$)$. The incidence was also higher in urban areas than in rural areas $(0.03$ vs. 0.01 per 100,000) (Table IV).

The highest number of $H$. influenzae type $B$ infections was recorded in the age group 25-44, which accounts for $40 \%$ of all infections caused by this etiological agent. In the age group $0-4$ years there were 2 cases (incidence -0.10 per 100,000) (Table V).

In 2019, the vaccination status of 2 year olds (primary vaccination) against $H$. influenzae in individual voivodeships ranged from $90.06 \%$ in podlaskie voivodeship to $98.4 \%$ in warmińskomazurskie voivodeship (4). krzyskie - o 40\%, województwo wielkopolskie - o 6\%. Ponadto, największa liczba zakażeń meningokokowych wystąpiła w I kwartale roku 2019 - 33 przypadki, następnie obserwowano spadek liczby zakażeń aż do III kwartału - 16 przypadków, po czym ponowny wzrost w IV kwartale - do 23 przypadków. Podobną tendencję zanotowano w roku 2018 (Tab. VI).

W 2019 r. liczba osób zaszczepionych przeciw chorobom wywoływanym przez $N$. meningitidis wyniosła 98 952, czyli o 0,74\% więcej niż w 2018 roku (98 223 osób). W tej grupie znalazło się 92,39 \% dzieci i młodzieży do 19 r.ż. (4).

Haemophilus influenzae typu B. Liczba zachorowań na zapalenie opon mózgowo-rdzeniowych i/lub mózgu wywołane przez $H$. influenzae typu $B$ wzrosła z 6 przypadków w 2018 roku do $10 \mathrm{w}$ roku 2019. Zapadalność pozostaje jednak na tym samym poziomie ze względu na ogólnie małą liczbe przypadków - 0,03 na 100 tys., zarówno w roku 2018 jak i w 2019 (Tab. II). W 2019 r. zachorowania zarejestrowano w 6 województwach: dolnoślasskim - 2 przypadki, mazowieckim -2 przypadki, podkarpackim - 1 przypadek, pomorskim - 1 przypadek, śląskim - 2 przypadki, zachodniopomorskim - 2 przypadki (1). Zapadalność wśród kobiet była wyższa niż u mężczyzn (0,03 vs. 0,02 na 100 tys.).

Table VI. Meningococcal disease: meningitis and/or encephalitis. Number of cases and incidence per 100,000 population by voivodeships in 2019

Tabela VI. Choroba meningokokowa: Zapalenie opon mózgowych i/lub mózgu. Liczba zachorowań oraz zapadalność na 100 tys. mieszkańców wg województw w 2019 roku

\begin{tabular}{|c|c|c|c|c|c|c|c|}
\hline \multirow{2}{*}{\multicolumn{2}{|c|}{$\begin{array}{l}\text { Województwo } \\
\text { (Voivodeship) }\end{array}$}} & \multicolumn{4}{|c|}{$\begin{array}{c}\text { Liczba zachorowań w kwartałach } \\
\text { (Number of cases in quarters) }\end{array}$} & \multirow{3}{*}{$\begin{array}{c}\begin{array}{c}\text { Liczba } \\
\text { zachorowan } \\
\text { (Number of } \\
\text { cases ) }\end{array} \\
102\end{array}$} & \multirow{3}{*}{$\begin{array}{c}\text { Zapadalność } \\
\text { na } 100 \text { tys. } \\
\text { (Incidence per } \\
100,000 \text { ) } \\
0,27\end{array}$} \\
\hline & & \multirow{2}{*}{$\begin{array}{c}\mathrm{I} \\
35 \\
\end{array}$} & \multirow{2}{*}{$\begin{array}{l}\text { II } \\
26\end{array}$} & \multirow{2}{*}{$\begin{array}{l}\text { III } \\
9\end{array}$} & \multirow{2}{*}{$\begin{array}{l}\text { IV } \\
32 \\
\end{array}$} & & \\
\hline Polska & $2018 \mathrm{r}$. & & & & & & \\
\hline (Poland) & $2019 \mathrm{r}$. & 33 & 23 & 16 & 23 & 95 & 0,25 \\
\hline \multicolumn{2}{|c|}{ Dolnośląskie } & 5 & 0 & 0 & 2 & 7 & 0,24 \\
\hline \multicolumn{2}{|c|}{ Kujawsko-pomorskie } & 1 & 1 & 0 & 1 & 3 & 0,14 \\
\hline \multicolumn{2}{|c|}{ Lubelskie } & 1 & 2 & 1 & 0 & 4 & 0,19 \\
\hline \multicolumn{2}{|c|}{ Lubuskie } & 0 & 2 & 0 & 0 & 2 & 0,20 \\
\hline \multicolumn{2}{|l|}{ Łódzkie } & 2 & 1 & 1 & 1 & 5 & 0,20 \\
\hline \multicolumn{2}{|c|}{ Małopolskie } & 1 & 2 & 0 & 1 & 4 & 0,12 \\
\hline \multicolumn{2}{|c|}{ Mazowieckie } & 3 & 2 & 6 & 4 & 15 & 0,28 \\
\hline \multicolumn{2}{|c|}{ Opolskie } & 0 & 1 & 1 & 0 & 2 & 0,20 \\
\hline \multicolumn{2}{|c|}{ Podkarpackie } & 3 & 0 & 2 & 0 & 5 & 0,24 \\
\hline \multicolumn{2}{|c|}{ Podlaskie } & 1 & 0 & 0 & 0 & 1 & 0,08 \\
\hline \multicolumn{2}{|c|}{ Pomorskie } & 3 & 0 & 0 & 3 & 6 & 0,26 \\
\hline \multicolumn{2}{|l|}{ Śląskie } & 3 & 3 & 1 & 2 & 9 & 0,20 \\
\hline \multicolumn{2}{|c|}{ Świętokrzyskie } & 0 & 2 & 2 & 1 & 5 & 0,40 \\
\hline \multicolumn{2}{|c|}{ Warmińsko-mazurskie } & 2 & 1 & 0 & 2 & 5 & 0,35 \\
\hline \multicolumn{2}{|c|}{ Wielkopolskie } & 7 & 2 & 2 & 5 & 16 & 0,46 \\
\hline \multicolumn{2}{|c|}{ Zachodniopomorskie } & 1 & 4 & 0 & 1 & 6 & 0,35 \\
\hline
\end{tabular}


Streptococcus pneumoniae. In 2019, a total of 181 cases were registered in Poland (incidence 0.47 per 100,000) of meningitis and encephalitis caused by S. pneumoniae (Table I). Compared to 2018, it was a decrease by $14.62 \%$. The highest number of cases was recorded in the voivodeships: śląskie and wielkopolskie -23 each. The incidence was respectively: 0.51 per 100,000 and 0.66 per 100,000 . On the other hand, the highest incidence was recorded in the zachodniopomorskie voivodeship: 0.71 per 100,000 , and the lowest in the podlaskie voivodeship: 0.08 per 100,000 (Table VII). The incidence of meningitis and encephalitis caused by $S$. pneumoniae was higher in urban areas than in rural areas $(0.49$ per 100,000 in urban areas and 0.44 per 100,000 in rural areas). In both urban and rural areas, we observed a decrease in incidence compared to 2018. $38.67 \%$ of all pneumococcal infections were recorded in the 45-64 age group. For comparison, in 2018 in this age group the highest number of infections was also observed (which was then $36.79 \%$ ). In the $0-4$ age group, the number of cases decreased by $25 \%$ compared to 2018 (24 cases in 2018 vs. 18 in 2019) (Table V).
Odnotowano także wyższą zapadalność w mieście niż na wsi (0,03 vs. 0,01 na 100 tys.) (Tab. IV).

Największą liczbę zakażeń $H$. influenzae typu $B$ odnotowano w grupie wieku 25-44 lata $-40 \%$ wszystkich zakażeń wywołanych przez ten czynnik etiologiczny. W grupie wieku 0-4 lata wystąpiły 2 zachorowania (zapadalność 0,10 na 100 tys.) (Tab. V).

W 2019 r. stan zaszczepienia dwulatków (szczepienie pierwotne) przeciw $H$. influenzae w poszczególnych województwach zawierał się $\mathrm{w}$ przedziale od $90,1 \%$ w województwie podlaskim do 98,4\% w województwie warmińsko-mazurskim (4).

Streptococcus pneumoniae. W 2019 r. zarejestrowano w Polsce ogółem 181 zachorowań (zapadalność 0,47 na 100 tys.) na zapalenie opon mózgowo-rdzeniowych i/lub mózgu wywołanych przez S. pneumoniae (Tab. I). W porównaniu do roku 2018, był to spadek o $14,62 \%$. Najwięcej zachorowań odnotowano w województwach śląskim i wielkopolskim - po 23. Zapadalność wyniosła odpowiednio: 0,51 na 100 tys. i 0,66 na 100 tys. Najwyższą zapadalność zanotowano w województwie zachodniopomorskim: 0,71 na 100 tys., a najniższą w województwie podlaskim: 0,08 na 100 tys. (Tab. VII). Zapadalność na zapalenie opon mózgowo-rdzeniowych

Table VII. Disease caused by S. pneumoniae: meningitis and/or encephalitis. Number of cases and incidence per 100,000 population by voivodeships in 2019

Tabela VII. Choroba wywołana przez S. pneumoniae, inwazyjna: Zapalenie opon mózgowych i/lub mózgu. Liczba zachorowań oraz zapadalność na 100 tys. mieszkańców wg województw w 2019 roku

\begin{tabular}{|c|c|c|c|c|c|c|c|}
\hline \multirow{2}{*}{\multicolumn{2}{|c|}{$\begin{array}{l}\text { Województwo } \\
\text { (Voivodeship) }\end{array}$}} & \multicolumn{4}{|c|}{$\begin{array}{l}\text { Liczba zachorowań w kwartałach } \\
\text { (Number of cases in quarters) }\end{array}$} & \multirow{3}{*}{$\begin{array}{c}\begin{array}{c}\text { Liczba } \\
\text { zachorowań } \\
\text { (Number of } \\
\text { cases ) }\end{array} \\
212\end{array}$} & \multirow{3}{*}{$\begin{array}{c}\text { Zapadalność } \\
\text { na } 100 \text { tys. } \\
\text { (Incidence per } \\
100,000) \\
0,55\end{array}$} \\
\hline & & \multirow{2}{*}{$\begin{array}{c}\mathrm{I} \\
68\end{array}$} & \multirow{2}{*}{$\frac{\text { II }}{60}$} & \multirow{2}{*}{$\begin{array}{l}\text { III } \\
35\end{array}$} & \multirow{2}{*}{$\begin{array}{l}\text { IV } \\
49\end{array}$} & & \\
\hline Polska & $2018 \mathrm{r}$. & & & & & & \\
\hline (Poland) & 2019 r. & 42 & 57 & 34 & 48 & 181 & 0,47 \\
\hline \multicolumn{2}{|c|}{ Dolnośląskie } & 6 & 2 & 3 & 3 & 14 & 0,48 \\
\hline \multicolumn{2}{|c|}{ Kujawsko-pomorskie } & 2 & 3 & 2 & 2 & 9 & 0,43 \\
\hline \multicolumn{2}{|c|}{ Lubelskie } & 2 & 2 & 1 & 3 & 8 & 0,38 \\
\hline \multicolumn{2}{|l|}{ Lubuskie } & 3 & 3 & 0 & 0 & 6 & 0,59 \\
\hline \multicolumn{2}{|l|}{ Łódzkie } & 0 & 6 & 0 & 5 & 11 & 0,45 \\
\hline \multicolumn{2}{|c|}{ Małopolskie } & 3 & 2 & 5 & 3 & 13 & 0,38 \\
\hline \multicolumn{2}{|c|}{ Mazowieckie } & 4 & 4 & 6 & 3 & 17 & 0,31 \\
\hline \multicolumn{2}{|l|}{ Opolskie } & 1 & 3 & 0 & 1 & 5 & 0,51 \\
\hline \multicolumn{2}{|c|}{ Podkarpackie } & 3 & 4 & 2 & 1 & 10 & 0,47 \\
\hline \multicolumn{2}{|c|}{ Podlaskie } & 0 & 1 & 0 & 0 & 1 & 0,08 \\
\hline \multicolumn{2}{|c|}{ Pomorskie } & 6 & 4 & 1 & 4 & 15 & 0,64 \\
\hline \multicolumn{2}{|l|}{ Śląskie } & 5 & 7 & 2 & 9 & 23 & 0,51 \\
\hline \multicolumn{2}{|c|}{ Świętokrzyskie } & 1 & 3 & 0 & 4 & 8 & 0,65 \\
\hline \multicolumn{2}{|c|}{ Warmińsko-mazurskie } & 0 & 3 & 1 & 2 & 6 & 0,42 \\
\hline \multicolumn{2}{|c|}{ Wielkopolskie } & 4 & 6 & 6 & 7 & 23 & 0,66 \\
\hline \multicolumn{2}{|c|}{ Zachodniopomorskie } & 2 & 4 & 5 & 1 & 12 & 0,71 \\
\hline
\end{tabular}


In 2019, 198,386 people were vaccinated against S. pneumoniae, the highest percentage of which was recorded in the mazowieckie voivodeship (14.93\%) (4).

Neuroborreliosis. A form of Lyme disease isolated under surveillance in Poland in 2019, classified as neuroinfection. In 2019, a total of 294 cases (incidence of 0.77 per 100,000) of neuroborreliosis were registered in Poland (Table VIII). Compared to 2018 year, there was a decrease of $25 \%$. The highest number of cases was recorded in the following voivodships: dolnośląskie (46 cases) and pomorskie (56 cases). The incidence was respectively: 1.59 per 100,000 and 2.4 per 100,000 . The highest incidence was recorded in the pomorskie voivodeship: 2.4 per 100,000 and the lowest in the mazowieckie voivodship: 0.22 per 100,000 (Table VIII). i/lub mózgu wywołane przez $S$. pneumoniae była wyższa w mieście niż na wsi $(0,49$ na 100 tys. na terenach miejskich oraz 0,44 na 100 tys. na obszarach wiejskich). Zarówno w przypadku obszarów miejskich jak i wsi obserwowano spadek zapadalności w porównaniu do roku 2018. 38,67\% wszystkich zakażeń pneumokokowych odnotowano w grupie wieku 45-64 lata. Dla porównania, w roku 2018 w tej grupie wieku również zaobserwowano najwięcej zakażeń (co stanowiło wówczas $36,79 \%$ ). W grupie wieku 0-4 lata, odnotowano spadek liczby zachorowań o 25\% względem roku 2018 (24 zachorowania w roku 2018 vs. 18 w roku 2019) (Tab. V).

W 2019 r., przeciw S. pneumoniae zaszczepiono 198386 osób, z czego największy odsetek odnotowano w województwie mazowieckim (14,93\%) (4).

Neuroborelioza. Postać boreliozy wyodrębniona w Polsce w nadzorze w 2019 r., zaliczana do neuroinfekcji. W 2019 r. zarejestrowano w Polsce ogółem 294 zachorowania (zapadalność 0,77 na 100 tys.) na neuroboreliozę (Tab. VIII). W porównaniu do roku 2018, jest to spadek o $25 \%$. Najwięcej zachorowań odnotowano w województwach: dolnośląskim (46 przypadków) i pomorskim (56 przypadków). Zapadalność wyniosła odpowiednio: 1,59 na 100 tys. i 2,4 na 100 tys. Najwyż-

Table VIII. Neuroborreliosis. Number of cases and incidence per 100,000 population by voivodeships in 2019

Tabela VIII. Neuroborelioza. Liczba zachorowań oraz zapadalność na 100 tys. mieszkańców wg województw w 2019 roku

\begin{tabular}{|c|c|c|c|c|c|c|c|}
\hline \multirow{2}{*}{\multicolumn{2}{|c|}{$\begin{array}{l}\text { Województwo } \\
\text { (Voivodeship) }\end{array}$}} & \multicolumn{4}{|c|}{$\begin{array}{l}\text { Liczba zachorowań w kwartałach } \\
\text { (Number of cases in quarters) }\end{array}$} & \multirow{3}{*}{$\begin{array}{c}\text { Liczba } \\
\text { zachorowań } \\
\text { (Number of } \\
\text { cases) } \\
392 *\end{array}$} & \multirow{3}{*}{$\begin{array}{c}\text { Zapadalność } \\
\text { na } 100 \text { tys. } \\
\text { (Incidence per } \\
100,000) \\
1,02^{*} \\
\end{array}$} \\
\hline & & \multirow{2}{*}{$\begin{array}{l}\mathrm{I} \\
- \\
\end{array}$} & \multirow{2}{*}{$\begin{array}{l}\text { II } \\
- \\
\end{array}$} & \multirow{2}{*}{$\begin{array}{c}\text { III } \\
- \\
\end{array}$} & \multirow{2}{*}{$\begin{array}{c}\text { IV } \\
-\end{array}$} & & \\
\hline Polska & $2018 \mathrm{r}$. & & & & & & \\
\hline (Poland) & 2019 r. & 52 & 36 & 96 & 110 & 294 & 0,77 \\
\hline \multicolumn{2}{|c|}{ Dolnośląskie } & 6 & 4 & 14 & 22 & 46 & 1,59 \\
\hline \multicolumn{2}{|c|}{ Kujawsko-pomorskie } & 2 & 2 & 4 & 3 & 11 & 0,53 \\
\hline \multicolumn{2}{|c|}{ Lubelskie } & 4 & 1 & 6 & 3 & 14 & 0,66 \\
\hline \multicolumn{2}{|c|}{ Lubuskie } & 1 & 0 & 2 & 1 & 4 & 0,39 \\
\hline \multicolumn{2}{|c|}{ Łódzkie } & 3 & 3 & 3 & 4 & 13 & 0,53 \\
\hline \multicolumn{2}{|c|}{ Małopolskie } & 3 & 1 & 5 & 8 & 17 & 0,50 \\
\hline \multicolumn{2}{|c|}{ Mazowieckie } & 2 & 2 & 2 & 6 & 12 & 0,22 \\
\hline \multicolumn{2}{|l|}{ Opolskie } & 2 & 1 & 6 & 5 & 14 & 1,42 \\
\hline \multicolumn{2}{|c|}{ Podkarpackie } & 6 & 5 & 6 & 10 & 27 & 1,27 \\
\hline \multicolumn{2}{|c|}{ Podlaskie } & 3 & 3 & 2 & 1 & 9 & 0,76 \\
\hline \multicolumn{2}{|c|}{ Pomorskie } & 9 & 7 & 18 & 22 & 56 & 2,40 \\
\hline \multicolumn{2}{|l|}{ Śląskie } & 5 & 2 & 11 & 10 & 28 & 0,62 \\
\hline \multicolumn{2}{|c|}{ Świętokrzyskie } & 1 & 1 & 1 & 6 & 9 & 0,73 \\
\hline \multicolumn{2}{|c|}{ Warmińsko-mazurskie } & 4 & 1 & 2 & 2 & 9 & 0,63 \\
\hline \multicolumn{2}{|c|}{ Wielkopolskie } & 0 & 2 & 4 & 2 & 8 & 0,23 \\
\hline \multicolumn{2}{|c|}{ Zachodniopomorskie } & 1 & 1 & 10 & 5 & 17 & 1,00 \\
\hline
\end{tabular}

*brak danych dla neuroboreliozy w związku z wprowadzeniem odrębnej rejestracji od 2019, wyliczone na potrzeby porównania

*no data for neuroborreliosis due to new registration method since 2019, calculated for comparison 


\section{VIRAL MENINGITIS AND ENCEPHALITIS}

In 2019 , a total of 1,318 cases of viral meningitis and/or encephalitis were recorded (incidence of 3,43 per 100,000 ), which is an decrease of $14.04 \%$ compared to 2018. In this group, most often $(61.2 \%)$ other specified and unspecified viral meningitis was diagnosed (807 cases; incidence of 2.1 per 100,000) (Table I).

Tick-borne encephalitis (TBE). In 2019, a total of 265 cases of tick-borne encephalitis (A84) were reported in 15 of 16 voivodeships (Table IX); incidence was 0.69 per 100,000 . Compared to 2018, the number of cases and the incidence increased; number of cases by $34.52 \%$ and incidence by $35.29 \%$. Most cases, as in previous years, were recorded in the north-eastern areas of Poland: in podlaskie $(40,75 \%$ of all cases) and warmińsko-mazurskie (17.74\% of all cases) voivodeships. The highest incidence of TBE was recorded in podlaskie and warmińsko-mazurskie voivodeships; it was, respectively: 9.16 and 3.3 per 100,000 , which compared to the previous year is a significant increase (in podlaskie voivodeship by $48 \%$, in warmińsko-mazurskie voivodeship by $188 \%$ ). In other voivodships, the incidence of KZM was below 1 per 100,000. (Table IX). The szą zapadalność zanotowano w województwie pomorskim: 2,4 na 100 tys., a najniższą w województwie mazowieckim: 0,22 na 100 tys. (Tab. VIII).

\section{ZAPALENIE OPON MÓZGOWO- RDZENIOWYCH I ZAPALENIE MÓZGU O ETIOLOGII WIRUSOWEJ}

W 2019 r. zarejestrowano ogółem 1318 przypadków zapaleń opon i/lub mózgu o etiologii wirusowej (zapadalność 3,43 na 100 tys.), co stanowi spadek o 14,04\% w stosunku do 2018 roku (8). W tej grupie najczęściej $(61,2 \%)$ diagnozowano zapalenia opon i/lub mózgu jako inne określone i nieokreślone wirusowe zapalenie opon mózgowo-rdzeniowych (807 przypadków; zapadalność 2,1 na 100 tys.) (Tab. I).

Kleszczowe zapalenie mózgu (KZM). W 2019 r. zgłoszono ogółem 265 zachorowań na kleszczowe zapalenie mózgu (A84) w 15 z 16 województw (Tab. IX); zapadalność wyniosła 0,69 na 100 tys. W porównaniu do 2018 r., liczba zachorowań oraz zapadalność wzrosły odpowiednio: o $34,52 \%$ i o $35,29 \%$. Najwięcej przypadków, podobnie jak w poprzednich latach, zarejestrowano na obszarach północno-wschodniej Polski: w województwie podlaskim $(40,75 \%$ ogółu zachorowań) oraz warmińsko-mazurskim (17,74\% wszystkich

Table IX. Tick-borne encephalitis. Number of cases and incidence per 100,000 population by voivodeships in 2019

Tabela IX. Kleszczowe zapalenie mózgu. Liczba zachorowań oraz zapadalność na 100 tys. mieszkańców wg województw w 2019 roku

\begin{tabular}{|c|c|c|c|c|c|c|c|}
\hline \multirow{2}{*}{\multicolumn{2}{|c|}{$\begin{array}{l}\text { Województwo } \\
\text { (Voivodeship) }\end{array}$}} & \multicolumn{4}{|c|}{$\begin{array}{c}\text { Liczba zachorowań w kwartałach } \\
\text { (Number of cases in quarters) }\end{array}$} & \multirow{3}{*}{$\begin{array}{c}\text { Liczba } \\
\text { zachorowań w } \\
\text { roku (Number } \\
\text { of cases - total) }\end{array}$} & \multirow{3}{*}{$\begin{array}{c}\text { Zapadalność } \\
\text { na } 100 \text { tys. } \\
\text { (Incidence per } \\
100,000) \\
0,51 \\
\end{array}$} \\
\hline & & \multirow{2}{*}{$\begin{array}{c}\mathrm{I} \\
12 \\
\end{array}$} & \multirow{2}{*}{$\begin{array}{l}\text { II } \\
31 \\
\end{array}$} & \multirow{2}{*}{$\begin{array}{l}\text { III } \\
83 \\
\end{array}$} & \multirow{2}{*}{$\begin{array}{l}\text { IV } \\
71 \\
\end{array}$} & & \\
\hline Polska & $2018 \mathrm{r}$. & & & & & & \\
\hline (Poland) & $2019 \mathrm{r}$. & 21 & 41 & 104 & 99 & 265 & 0,69 \\
\hline \multicolumn{2}{|c|}{ Dolnośląskie } & 2 & 2 & 12 & 11 & 27 & 0,93 \\
\hline \multicolumn{2}{|c|}{ Kujawsko-pomorskie } & 0 & 1 & 1 & 1 & 3 & 0,14 \\
\hline \multicolumn{2}{|c|}{ Lubelskie } & 3 & 2 & 7 & 4 & 16 & 0,76 \\
\hline \multicolumn{2}{|l|}{ Lubuskie } & 0 & 0 & 0 & 0 & 0 & 0 \\
\hline \multicolumn{2}{|l|}{ Łódzkie } & 3 & 0 & 3 & 6 & 12 & 0,49 \\
\hline \multicolumn{2}{|c|}{ Małopolskie } & 2 & 2 & 3 & 6 & 13 & 0,38 \\
\hline \multicolumn{2}{|c|}{ Mazowieckie } & 0 & 3 & 9 & 5 & 17 & 0,31 \\
\hline \multicolumn{2}{|l|}{ Opolskie } & 0 & 0 & 1 & 2 & 3 & 0,30 \\
\hline \multicolumn{2}{|c|}{ Podkarpackie } & 0 & 0 & 1 & 0 & 1 & 0,05 \\
\hline \multicolumn{2}{|l|}{ Podlaskie } & 9 & 20 & 39 & 40 & 108 & 9,16 \\
\hline \multicolumn{2}{|c|}{ Pomorskie } & 0 & 0 & 1 & 0 & 1 & 0,04 \\
\hline \multicolumn{2}{|l|}{ Śląskie } & 1 & 0 & 2 & 1 & 4 & 0,09 \\
\hline \multicolumn{2}{|c|}{ Świętokrzyskie } & 1 & 0 & 4 & 3 & 8 & 0,65 \\
\hline \multicolumn{2}{|c|}{ Warmińsko-mazurskie } & 0 & 9 & 20 & 18 & 47 & 3,30 \\
\hline \multicolumn{2}{|c|}{ Wielkopolskie } & 0 & 1 & 0 & 0 & 1 & 0,03 \\
\hline \multicolumn{2}{|c|}{ Zachodniopomorskie } & 0 & 1 & 1 & 2 & 4 & 0,24 \\
\hline
\end{tabular}


risk of tick-borne encephalitis is greater for people spending time near forests or in the woods, whether it is for recreation or work. That is why TBE most often concerns forest workers, farmers, students and pensiones (9).

In 2019 , a total of 87,917 people received a last dose of the TBE primary vaccination course or a booster dose, i.e. 28,919 people $(49.02 \%)$ more compared to 2018. Most people were vaccinated in mazowieckie voivodeship 26,680 ; least in lubuskie voivodeship $-1,239$ people. The increase in number of people vaccinated against TBE indicates an increase in the awareness of society regarding the disease and the possibility of prevention through vaccination (4).

\section{SUMMARY AND CONCLUSION}

In summary, in 2019, we observed a general downward trend in cases of both bacterial and viral meningitis and /or encephalitis. The exceptions are cases caused by $H$. influenza and TBE cases, where an increase was recorded compared to the previous year. In 2019, 19.9\% less cases of meningitis and encephalitis were registered in Poland compared to 2018. The presentation of cases by age group shows very well that the introduction of mandatory vaccination against $S$. pneumoniae has been producing very good results since 2017 (most cases were adults). Vaccination against meningococcus still remains in the recommended group. It seems that the introduction of mandatory vaccination against $N$. meningitidis, proposed by experts, could further reduce the number of cases in the long run. In the case of TBE, we observed an increase in the number of cases. In addition, however, the number of vaccinated people also increased, which may indicate an increase in public awareness of the etiology of the disease and the possibility of prevention through vaccination.

\section{REFERENCES}

1. Mount RH, Boyle DS. Aseptic and Bacterial Meningitis: Evaluation, Treatment, and Prevention. American Family Physician. 2017;1;96(5):314-322.

2. Brueggemann AB, Jansen van Rensburg JM, Shaw D, et al. Changes in the incidence of invasive disease due to Streptococcus pneumoniae, Haemophilus influenzae, and Neisseria meningitidis during the COVID-19 pandemic in 26 countries and territories in the Invasive Respiratory Infection Surveillance Initiative: a prospective analysis of surveillance zachorowań). Największą zapadalność na KZM zanotowano w województwie podlaskim, a następnie w warmińsko-mazurskim; wyniosła ona odpowiednio: 9,16 oraz 3,3 na 100 tys., co w porównaniu do poprzedniego roku było znaczącym wzrostem (w województwie podlaskim o $48 \%$, a w warmińsko-mazurskim o $188 \%$ ). W pozostałych województwach zapadalność na KZM była poniżej 1 na 100 tys. (Tab. IX). Ryzyko zachorowania na kleszczowe zapalenie mózgu jest większe dla osób spędzających czas w okolicach zalesionych, niezależnie, czy dotyczy to rekreacji, czy pracy zawodowej. KZM najczęściej dotyczy pracowników leśnych, rolników, młodzieży oraz emerytów (9).

W 2019 r. dawkę szczepionki przeciw KZM kończącą cykl szczepienia podstawowego lub dawkę przypominającą otrzymało łącznie 87917 osób, tj. o 28919 osób (49,02\%) więcej niż w 2018 r. Najwięcej osób zaszczepiono w województwie mazowieckim 26 680, natomiast najmniej w województwie lubuskim - 1239 osób. Wzrost liczby osób zaszczepionych przeciw KZM wskazuje na wzrost świadomości społeczeństwa dotyczący samej choroby oraz możliwości jej zapobiegania poprzez szczepienia (4).

\section{PODSUMOWANIE I WNIOSKI}

Podsumowując, w roku 2019 obserwowano ogólną tendencję spadkową zachorowań, zarówno w przypadku zapaleń opon mózgowych i/lub mózgu o etiologii bakteryjnej, jak i wirusowej. Wyjątek stanowią zachorowania wywołane przez $H$. influenzae, gdzie zanotowano wzrost względem roku poprzedniego oraz KZM. W roku 2019, zarejestrowano w Polsce o 19,9\% mniej zachorowań na zapalenia opon mózgowo-rdzeniowych i/lub mózgu w porównaniu do roku 2018 (9). Ocena zachorowań w podziale na grupy wieku dobrze obrazuje, że wprowadzenie obowiązku szczepień przeciw $S$. pneumoniae od 2017 roku przynosi bardzo dobre rezultaty (większość zachorowań dotyczyła osób dorosłych). Szczepienia przeciw meningokokom nadal pozostają w grupie szczepień zalecanych. Wydaje się, że proponowane przez ekspertów wprowadzenie obowiązku szczepień przeciw N. meningitidis mogłoby w dłuższej perspektywie jeszcze bardziej zredukować liczbę zachorowań. W przypadku KZM obserwowano wzrost liczby zachorowań przy jednoczesnym wzroście liczby osób zaszczepionych, co wskazywać może na wzrost świadomości społeczeństwa w zakresie choroby oraz możliwości zapobiegania jej poprzez szczepienia. 
data. Lancet Digit Health 2021;3(6):360-370 doi: 10.1016/S2589-7500(21)00077-7.

3. Król ME, Borawski B, Nowicka-Ciełuszecka A et al. Outbreak of alimentary tick-borne encephalitis in Podlaskie voivodeship, Poland / Ognisko zachorowań na kleszczowe zapalenie mózgu nabyte drogą pokarmową na terenie województwa podlaskiego. Przegl Epidemiol 2019;73(2):239-248. doi: 10.32394/pe.73.01.

4. Szczepienia ochronne w Polsce w 2019 roku, Czarkowski MP. i in., 2020, Warszawa, NIZPPZH, GIS.

5. Fouad R, Khairy M, Fathalah W et al. A. Role of Clinical Presentations and Routine CSF Analysis in the Rapid Diagnosis of Acute Bacterial Meningitis in Cases of Negative Gram Stained Smears. J Trop Med. 2014;2014:213762. doi: 10.1155/2014/213762.

6. Wright FW, Pinto NC, Palisoc K, Baghli S. Viral (aseptic) meningitis: A review. J Neurol Sci. 2019;15;398:176-183 doi: 10.1016/j.jns.2019.01.050.

7. Choroby zakaźne i zatrucia w Polsce w 2019 roku, Czarkowski MP. i in., 2020, Warszawa, NIZP-PZH, GIS.

8. Zbrzeźniak J, Paradowska-Stankiewicz I. Meningitis and encephalitis in Poland in 2018 / Zapalenia opon mózgowo-rdzeniowych i zapalenia mózgu w Polsce w 2018 roku. Przegl Epidemiol 2021; 75(1):63-75

9. Stefanoff P, Rosinska M, Samuels $S$ et al. A national case-control study identifies human socio-economic status and activities as risk factors for tick-borne encephalitis in Poland. PLoS One. 2012;7(9):e45511. doi: 10.1371/journal. pone. 0045511

Received: 04.08.2021

Accepted for publication: 06.09.2021

Otrzymano: 04.08.2021 r.

Zaakceptowano do publikacji: 06.09.2021 r.

\section{Address for correspondence:}

Adres do korespondencji:

Iwona Paradowska-Stankiewicz, MD, PhD

Department of Epidemiology of Infectious Diseases and Surveillance

National Institute of Public Health NIH - NRI

24 Chocimska Str.

00-791 Warsaw

e-mail: istankiewicz@pzh.gov.pl 